\title{
CHANGES IN QTC INTERVAL DURATION AMONG HEROIN ADDICTS ON METHADONE TREATMENT
}

Mirjana Jovanovic ${ }^{1}$, Mladen Divnic ${ }^{2}$, Milan Jovanovic ${ }^{2}$, Sasa Babic ${ }^{1}$, Katarina Nikic Djuricic ${ }^{1}$, Andrea Obradovic ${ }^{1}$

${ }^{1}$ Clinic of Psychiatry, Clinical Center in Kragujevac, Kragujevac, Serbia

${ }^{2} \mathrm{NGO}$ Alternative Youth Center

\author{
PROMENE U TRAJANJU QTC INTERVALA \\ KOD HEROINSKIH ZAVISNIKA NA METADONKOM TRETMANU \\ Mirjana Jovanović ${ }^{1}$, Mladen Divnić ${ }^{2}$, Milan Jovanović ${ }^{2}$, Saša Babić ${ }^{1}$, Katarina Nikić Đuričić ${ }^{1}$, Andrea Obradović ${ }^{1}$ \\ ${ }^{1}$ Psihijatrijska klinika, Klinički Centar Kragujevac, Kragujevac, Srbija \\ ${ }^{2} \mathrm{NVO}$ Alternativni omladinski centar
}

Received / Primljen: 28.09.2014.

Accepted / Prihvaćen: 21.08.2015.

\begin{abstract}
This paper aimed to collect and unite facts known about the effect of methadone treatment on QTc interval prolongation that could determine precipitating factors in the development of heart arrhythmias and their consequences (Torsade de Pointes and sudden cardiac death), and to raise the methadone treatment safety level.

Studies conducted up to now clearly demonstrate that methadone therapy evokes changes in the heart's electrical conduction, but those studies also show that QTc interval prolongation could be precipitated by other factors. The most often present risk factors in our research were dose of methadone, co-medication, and co-morbidity, but other relevant risk factors were gender, age, misuse of illicit drugs, therapy length and tobacco use.

Active participation in modern treatment processes and implementation of knowledge acquired recently into daily practice, such as setting up reutilized questionnaires and diagnostic methods to expose higher risk for complications and providing broader therapeutic range for cases of drug replacement necessity, will enhance therapy safety level and bring us to the next step of resocialization of these patients, which needs to remain the final goal of treatment.

Keywords: methadone treatment, QTc interval prolongation, Torsade de Pointes, sudden cardiac death
\end{abstract}

\section{SAŽETAK}

Cilj ovog preglednog članka je da prikupi $i$ objedini do sada poznate činjenice, o efektima metadonske terapije na produženje QTc intervala, koje mogu da ukažu na predisponirajuće faktore za nastanak srčanih aritmija $i$ njihovih posledica (Torsade de Pointes, iznenadna srčana smrt) kao i da unaprede sigurnost prilikom upotrebe ove terapije. Studije sprovedene do sada definitivno pokazuju da terapija metadonom izaziva promene u električnoj provodljivosti srca, ali i da produženje QTc intervala može da bude uslovljeno i drugim faktorima. U najčešće faktore rizika se ubrajaju doza metadona, udružena terapija, ko-morbiditet, pol, starost, zloupotreba ilegalnih droga, dužina terapije $i$ konzumiranje duvana. Aktivno učešce u modernim terapijskim procedurama $i$ uključivanje do sada stečenih znanja u rutinsku praksu (putem uvodjenja upitnika i dijagnostičkih metoda) radi utvrdivanja rizika za nastanak komplikacija $i$ obezbedjivanja šireg terapeutskog spectra, će podići nivo sigurnosti prilikom upotrebe lekova $i$ dovesti nas do sledećeg koraka - resocijalizacije pacijenata, što treba da ostane krajnji cilj terapije.

Ključne reči: terapija metadonom, produženje QTc intervala, Torsade de Pointes, iznenadna srčana smrt

\section{INTRODUCTION}

Methadone is the most commonly used drug in opioid maintenance treatment, and it has been on the WHO's list of essential medicines since 2005 (1); however, it was also noted by the FDA in 2006 as a drug with serious side effects, such as respiratory centre depression and cardiac dysrhythmia (2). The assumption is that methadone causes cardiac dysrhythmia by prolonging QTc interval, which is a risk for Torsade de Pointes that could evolve into sudden cardiac death.
Although methadone therapy has been used for over 40 years to treat opioid addiction, its side effects were first seriously indicated in 2006 (2), when numerous studies were published. However, there was no adequate experimental clinical study (3). A lack of controlled randomized studies with a placebo group was justified by the specific characteristics of this disease and the necessity for constant therapy. Meanwhile, in recent years, important compara- 
tive experimental studies have been published with results demonstrating new approaches towards the abovementioned problems.

The main questions on this topic are as follows: does methadone cause prolongation of QT interval, does methadone prolong QT interval enough to cause ventricular tachycardia, and is QT interval length subject to other factors present among these patients?

This review aimed to both summarize previous knowledge on this topic and to note the newest research in comparative and other clinical studies and thus consolidate knowledge in the area of methadone maintenance treatment (MMT) to improve the safety of patients receiving therapy for heroin addiction.

\section{Methadone}

Methadone, a synthetic agonist of mu receptors, is administered orally for the treatment of opioid addiction, and it is most often used as a racemic mixture of R- and S-enantiomers. Whereas R-enantiomer mostly causes an opioid effect (4), both R-and S-enantiomers function like an antagonist of N-methyl- D-aspartic acid (NMDA) (5). Oral bioavailability of methadone is $70-90 \%$, and it is transported bound to plasma proteins (6). It is metabolized in the liver by the cytochrome P450 enzyme system - mainly by CYP3A4 and CYP2B6 - whose activities are genetically and environmentally determined (7). It is important to note the stereo selectivity of the CYP2B6 enzyme towards S-methadone, which has been shown in vitro (8) and confirmed in vivo by showing that this enzyme is a slower metabolizer of methadone and thus produces higher S-methadone serum levels in people with the CYP2B6 genotype (9). Additionally, there are certain drugs that are metabolized by or inhibit these enzymes that may increase plasma methadone levels (10).

The most effective dosage of methadone for opioid dependence treatment is 60-100 mg per day (11).

\section{Qt Interval}

The length of the QT interval, which is the time between the start of the $\mathrm{Q}$ wave and the end of the $\mathrm{T}$ wave in the heart's electrical cycle, is predictive of Torsade de Pointes, which can be fatal (12). QT interval is corrected by Bazett's formula (QTc) because it is dependent on the heart rate (13). Normal QTc interval is considered $<430 \mathrm{~ms}$ in men and $<450 \mathrm{~ms}$ in women, whereas a prolonged QTc interval has been defined as $>450 \mathrm{~ms}$ for men and $>470$ ms for women (14). TdP will not follow every QTc interval prolongation, but QTc prolongation over $500 \mathrm{~ms}$ significantly increases the risk of TdP (15).

Studies on congenital long QT syndrome have provided an underlying reason for QT prolongation. Numerous mutations of the KCNH2 gene that code the human ethera'-gogo related gene (hERG) voltage-gated potassium channel in the human heart are responsible for congeni- tal long QT syndrome and sudden death caused by malignant ventricular arrhythmias (16). The importance of these channels among OMT patients became clearer (17) when it was shown that hERG channels might be blocked by some drugs, like methadone (18).

\section{METHODS}

We searched the PubMed database using the following key words: Methadone maintenance treatment, and QTC prolongation with the following filters: Publication date from 1980/01/01 to 2013/01/01, Clinical Trial, Randomized Controlled Trial, Humans and English. We obtained 4 search results.

In order to complete our research, we obtained additionally used research papers connected to results from our basic search (Related citations in PubMed) that were offered together with the results from the basic search.

Not all of the results obtained this way fit within our topic of interest, so our research team divided into four groups that independently reviewed gathered research papers to identify common parameters to select the research papers of interest. Included parameters were Methadone maintenance treatment and QTc prolongation as the topic of the research papers.

After an independent review of the research papers, all 4 groups held a meeting, excluded research papers that appeared in more than one group, and once more reviewed the rest of the research papers with the aim of determining that they all included the appropriate parameters. This method brought us a satisfactory number of research papers and increased the amount of literature to be used as source of information on this topic.

Another limitation we faced at this stage was that a great number of research papers obtained through the PubMed database contained only abstracts. We tried to overcome this by sending appeals to the authors of these papers asking for the full research paper for the review to be as complete as possible. In this way, we gained full access to the majority of the research papers.

Additionally, research papers that were not in our PubMed database search but were accessible to team members were used as information sources but will be not found in the RESULTS section because they were not the result of PubMed database search.

\section{RESULTS}

\section{Experimental studies}

In 2008, Wieneke et al. published a randomized, controlled clinical trial that compared LAAM with methadone (19). The methadone group consisted of patients on MMT for at least one month and with a stabile methadone dosage (less than $100 \mathrm{mg} /$ day) for at least two 
weeks. Exclusion criteria were used to form groups of patients without cardiac disease, serious psychiatric diseases or somatic disorders and with negative urine drug screen for opiates during the screening period. After 4 weeks of methadone therapy, patients were randomized into two groups (group treated with LAAM and group treated with methadone) and followed for 24 more weeks. For the purpose of this review, only the methadone group is described. The 22 patients in the methadone group had a mean age of 31 years. Twelve patients were women. The mean methadone dose before randomization was $72.0 \pm$ $25.5 \mathrm{mg} /$ day compared to $69 \pm 27.6 \mathrm{mg} /$ day in the next phase. This study did not show significant changes in QTc interval, which varied from $406 \mathrm{~ms} \pm 29 \mathrm{~ms}$ at the beginning to $405 \mathrm{~ms} \pm 25 \mathrm{~ms}$ after 24 weeks.

Another study compared different medicines in the treatment of heroin addiction (20). An advantage of the study performed by Wedam et al. was its design, a randomized, double-blinded study, but it lacked a placebo group for ethical reasons. At the beginning of the study, the mean QTc interval was $412.6 \mathrm{~ms}$, and after 16 weeks, the mean QTc interval increased to $446.9 \mathrm{~ms}$. Among 53 participants in the methadone group, $23 \%$ had QTc intervals longer than $470 \mathrm{~ms}$ for males and $490 \mathrm{~ms}$ for females, and 6 participants in the study developed QTc interval values over $500 \mathrm{~ms}$. It is important to mention that $12 \%$ of participants had QTc intervals that lengthened by more than 60 ms compared with baseline values. The methadone dose used varied from 60 to $100 \mathrm{mg}$.

\section{Observational studies}

In 2008, Krantz conducted a prospective cohort study with 151 participants with the aim to evaluate the influence of methadone on QTc interval length (21). After selecting the participants, a baseline ECG was performed followed by a second ECG after 6 months. The results showed that QTc interval prolongation was present among $76 \%$ of patients on methadone, whereas the rest of the patients did not have prolongation or the QTc interval length was shortened. Specifically, QTc intervals over $450 \mathrm{~ms}$ were found among $7 \%$ of patients at the baseline ECG and among $19 \%$ after 6 months. A QTc interval over $470 \mathrm{~ms}$ was present in 3\% of patients at the first ECG and in 7\% at the second ECG. There was no case of a QTc interval longer than $500 \mathrm{~ms}$ at the baseline ECG, but this value was exceeded in $2 \%$ of patients after 6 months of study. None of the patients developed TdP during the study. The practical implications of the study were a non-significant prolongation of the QTc interval of less than $30 \mathrm{~ms}$ among $18 \%$ of participants, but a clinically more significant prolongation of more than $60 \mathrm{~ms}$ compared to the baseline ECG was present among $3 \%$ of patients.

Another prospective study performed by Krantz et al. gathered 118 newly recruited patients of an MMT program who started therapy with a $30 \mathrm{mg}$ daily methadone dose that was afterwards adjusted based on information about previous heroin use, clinical assessment of withdrawal symptoms, and illicit opiate usage proved by urine analysis (22). Baseline QTc values varied from 367 to 483 $\mathrm{ms}$ (mean value $415.3 \mathrm{~ms}$ ) but increased to $376-533 \mathrm{~ms}$ (mean value $429.4 \mathrm{~ms}$ ) after 6 months. As the upper limit of normal QTc values was considered $430 \mathrm{~ms}$ for males and $450 \mathrm{~ms}$ for females, this resulted in QTc interval prolongation among $14 \%$ of patients at the beginning of the study and $31 \%$ at the end. The methadone doses used varied from 20-180 mg per day. However, Martel et al. continued the study and added an ECG performed after 12 months from the beginning of the study (23). The difference was that for this study, the upper limit of the normal QTc values was set $450 \mathrm{~ms}$ for men and $470 \mathrm{~ms}$ for women. Under these conditions, just 3\% of patients had prolonged QTc values at the baseline ECG and 24\% had prolonged QTc values after 6 months. At the end of the study, $22 \%$ had prolonged QTc values, and 2 participants had QTc values over $500 \mathrm{~ms}$ (23).

A study with 83 patients who were on MMT for longer than 6 months with a steady maintenance daily dose and with methadone as the only used medication showed 2 patients with QTc intervals longer than $500 \mathrm{~ms}$, but neither patient had ever experienced symptoms of a heart disorder (24). Maremmani et al. found 69 patients (83.1\%) with prolonged QTc intervals beyond the upper limits of normal QTc values of $440 \mathrm{~ms}$ in males and $460 \mathrm{~ms}$ in females. Patients did not have an electrolyte imbalance and had a negative urine test for cocaine, morphine and amphetamines. The researchers concluded that there was an absence of proof that methadone had no effect on cardiac function, but they did not find any correlation between QTc length and methadone dose. Additionally, due to the fact that there were only two cases of QTc intervals longer than $500 \mathrm{~ms}$, they speculated that there was no risk of arrhythmia among MMT patients as long as methadone was administered as the only therapy.

Mayet with a group of scientists conducted a crosssectional study on the prevalence of QT prolongation among patients on MMT and the appearance of $\mathrm{TdP}$ (25). The study group consisted of patients who fulfilled the criteria proposed by The Medicines and Healthcare Products Regulatory Agency (patients on methadone with heart/liver disease, electrolyte abnormalities, concomitant QT prolonging medications/CYP3A4 inhibitors or prescribed methadone $>100 \mathrm{mg}$ daily) (26). This research showed that the prevalence of QTc prolongation ( $>450 \mathrm{~ms}$ for males and $>470 \mathrm{~ms}$ for females) was $18.1 \%$, whereas there was neither QTc prolongation over $500 \mathrm{~ms}$ nor the occurrence of TdP.

Researchers from France followed a group of 42 outpatients by measuring the QTc interval during their visits to the centre for treatment of addiction diseases. Independently, they searched through the French pharmacovigilance medical reports database dating from 1996 to 2007 and singled out reports of cardiac symptoms connected to methadone treatment. The results of both studies were published separately (27). They recorded data on co-med- 
ication, comorbidity, electrolyte status, and psychoactive substance abuse. The study started with 100 patients, although an ECG was obtained from only 42 patients, and showed QTc interval prolongation among 4 patients with a maximal prolongation of $36 \mathrm{~ms}$ compared to the reference values.

Another cross-sectional study followed patients on medication treatment for addiction with the aim to define the prevalence of QTc prolongation. This study collected data from a registry of all patients on medication treatment for addiction in Norway from 1997 to 2003 for the purpose of discovering mortality that was potentially caused by therapy (28). The cross-sectional study involved $173 \mathrm{pa}-$ tients treated with methadone, and among them, 4.6\% ( $\mathrm{n}=$ 8) had a QTc interval above 500 milliseconds, $15 \%(n=26)$ had a QTc interval above 470 milliseconds, and 28.9\% ( $\mathrm{n}=$ 50) had a QTc interval above 450 milliseconds.

Another study included 138 patients who were on treatment for at least 100 days and on a stable methadone dose for at least 14 days as well as 111 (80.4\%) patients who received more than $120 \mathrm{mg} /$ day of methadone. This study measured methadone serum levels and QTc interval (29) and reported several comorbidities, 76 patients were positive for $\mathrm{HCV}$ and 11 were positive for HIV, as well as drug abuse. The results showed only 3 patients with QTc intervals longer than $500 \mathrm{~ms}$ (upper limit of normal and clinically relevant in this study) and found no correlation between QTc interval and methadone doses and serum levels. This study did find a significant correlation between methadone dose and QTc interval among 31 patients with urine positive for cocaine, but did not find a significant correlation among patients abusing other drugs (e.g., benzodiazepine, opiate, cannabis, amphetamine).

The cross-sectional study conducted by Eap et al. found 9\% of patients with QTc prolongation among 179 patients on methadone treatment (30). All of the QTc prolongations occurred in men. Patients were on MMT for at least 6 months at the time when the study was conducted, with the exception of 9 participants with the lowest duration of treatment being 2 months. Methadone plasma concentrations were in steady state in all except one patient.

The studies that provided the most detailed data for patients on methadone treatment were clinical cases. Although these studies do not provide statistical values, they clearly show an interaction between methadone dosage, risk factors, and QTc values.

A clinical case of a 52-year-old, HIV+, female patient without previous cardiologic problems but with prolonged QTc interval and occurrence of TdP after a high dose of methadone was described by Denise D. Routhier et al. (31), suggesting the ability of methadone to induce QTc prolongation and Torsade de Pointes. Additional data showed that this patient arrived at the hospital with hypokalaemia and hypomagnesemia even though the serum $\mathrm{K}+$ and $\mathrm{Mg}++$ concentrations were normal at the time of the arrest. Additionally, a urine drug screen was positive for cocaine and benzodiazepines as well as other medications, among them alprazolam, which shares in CYP3A4 metabolism. The patient was diagnosed with hepatitis B and C, but the liver function was good. Daily dosage of methadone was $145 \mathrm{mg}$, and when gradually reduced to $80 \mathrm{mg}$, QTc interval narrowed from $618 \mathrm{~ms}$ to $503 \mathrm{~ms}$ on hospital day 4 and to $454 \mathrm{~ms}$ on day 19, at the time of discharge. Another group of scientists from the University of Pittsburgh wrote a case report on this patient, concluding that TdP occurred due to its multifactorial aetiology (32).

Another case series presented 4 patients with prolonged QTc interval and arrhythmias while on high doses of methadone (33). Here, there were also other risk factors such as hypokalaemia (among 3 patients), co-medication, abuse of illicit substances and structural heart disease. Although the authors stated that methadone treatment was continued in all 4 cases and that QTc interval was normalized and arrhythmias vanished when risk factors were suppressed, they concluded that methadone should be on the list of drugs that can produce QTc interval prolongation and TdP.

\section{DISCUSSION}

After our literature search, we need to mention couple of limitations in the research on methadone maintenance treatment programs. The biggest limitation is a lack of experimental clinical trials with placebo groups, which are impossible for ethical reasons. Other limitations are connected to the specific behaviour of patients. Almost every study faced the problem of patients ending participation in the research.

However, in recent years, progress has been made, and a couple of experimental clinical studies that compared the effect of methadone and other medications in opioid dependence treatment have been published. Additionally, new insight into the effect of methadone on QTc interval was given by in vitro studies that tested the consequences of different genotypes on QTc interval.

Does methadone therapy lead to QTc interval prolongation among MMT patients? It was impossible to systematically analyse study results using only one reference value (Table 1). The most often used reference values for QTc were the ones proposed by the Committee for Proprietary Medicinal Products (CPMP) (14). Nevertheless, many authors used different reference values (20-29), which made it impossible to produce comprehensive results using the given data. Some authors preferred to measure QTc prolongation as an absolute increase in QTc. $(20,21,22)$. According to the International Conference on Harmonization, absolute increases greater than $30 \mathrm{~ms}$ and greater than 60 ms are important (34), which is a good way to describe the influence of methadone on QTc interval at baseline values. However, despite all the problems mentioned above, there were patients on methadone maintenance programs with prolongation in QTc interval. 
Table 1: References used for interpretation of QTc values.

\begin{tabular}{|c|c|c|}
\hline Name of the study & Reference & Values \\
\hline $\begin{array}{l}\text { QT interval prolongation: prevalence, risk } \\
\text { factors and pharmacovigilance data among } \\
\text { methadone-treated patients in France. } \\
\text { Perrin-Terrin A, Pathak A, Lapeyre-Mestre } \\
\text { M. }\end{array}$ & Reference not stated & $\begin{array}{l}3(7.1 \%)>450 \mathrm{~ms} \text { for males } \\
0>470 \mathrm{~ms} \text { for females }\end{array}$ \\
\hline $\begin{array}{l}\text { Methadone maintenance, QTc and torsade } \\
\text { de pointes: who needs an electrocardiogram } \\
\text { and what is the prevalence of QTc } \\
\text { prolongation? } \\
\text { Mayet S, Gossop M, Lintzeris N, Markides } \\
\text { V, Strang J. }\end{array}$ & $\begin{array}{l}\text { Moss AJ. Measurement of the QT interval and the risk associated with } \\
\text { QTc interval prolongation: a review. Am J Cardiol 1993;72:23B-5B. }\end{array}$ & $\begin{array}{l}13(15.7 \%) \geq 450 \mathrm{~ms} \text { for males } \\
2(2.4 \%) \geq 470 \mathrm{~ms} \text { for females }\end{array}$ \\
\hline $\begin{array}{l}\text { Prevalence and clinical relevance of } \\
\text { corrected QT interval prolongation during } \\
\text { methadone and buprenorphine treatment: a } \\
\text { mortality assessment study. } \\
\text { Anchersen K, Clausen T, Gossop M, Hansteen } \\
\text { V, Waal H. }\end{array}$ & $\begin{array}{l}\text { Krantz M. J. Heterogeneous impact of methadone on the QTc interval: } \\
\text { what are the clinical implications? J Addict Dis 2008; 27: 5-9. }\end{array}$ & $\begin{array}{l}85(49.1 \%)>430 \mathrm{~ms} \\
50(28.9 \%)>450 \mathrm{~ms} \\
26(15 \%)>470 \mathrm{~ms} \\
8(4.6 \%)>500 \mathrm{~ms}\end{array}$ \\
\hline $\begin{array}{l}\text { Heterogeneous impact of methadone on } \\
\text { the QTc interval: what are the practical } \\
\text { implications? } \\
\text { Krantz MJ }\end{array}$ & Author set reference values & $\begin{array}{l}62(41 \%)>430 \mathrm{~ms} \\
29(19 \%)>450 \mathrm{~ms} \\
11(7 \%)>470 \mathrm{~ms} \\
3(2 \%)>500\end{array}$ \\
\hline $\begin{array}{c}\text { Corrected-QT intervals as related to } \\
\text { methadone dose and serum level in } \\
\text { methadone maintenance treatment (MMT) } \\
\text { patients: a cross-sectional study. } \\
\text { Peles E, Bodner G, Kreek MJ, Rados V, } \\
\text { Adelson } M .\end{array}$ & $\begin{array}{l}\text { Moss A. J., Zareba W., Benhorin J., Couderc J. P., Kennedy H., Locati-Heilbron } \\
\text { E. et al. ISHNE guidelines for electrocardiographic evaluation of drug-related } \\
\text { QT prolongation and other alterations in ventricular repolarization: task force } \\
\text { summary. A report of the Task Force of the International Society for Holter } \\
\text { and Noninvasive Electrocardiology (ISHNE), Committee on Ventricular } \\
\text { Repolarization. Ann Noninvasive Electrocardiol 2001; 6: 333-41. }\end{array}$ & $\begin{array}{l}12(7.9 \%) \geq 450 \mathrm{~ms} \\
7(4.6 \%) 500>\text { QTc } \geq 460 \mathrm{~ms} \\
3(2 \%)>500 \mathrm{~ms}\end{array}$ \\
\hline $\begin{array}{l}\text { QTc interval prolongation in patients on } \\
\text { long-term methadone maintenance therapy. } \\
\text { Maremmani I, Pacini M, Cesaroni } C \text {, } \\
\text { Lovrecic M, Perugi G, Tagliamonte A. }\end{array}$ & $\begin{array}{l}\text { Vincent GM, Timothy K, Leppert M, Keating M: The spectrum of } \\
\text { symptoms and QT interval in carriers of the gene for the long-QT } \\
\text { syndrome. N Engl J Med 1992; 327:846-852. }\end{array}$ & $\begin{array}{l}2(2.4 \%)>470 \mathrm{~ms} \text { for males } \\
0>480 \mathrm{~ms} \text { for females }\end{array}$ \\
\hline $\begin{array}{c}\text { Levo-alpha-acetylmethadol (LAAM) } \\
\text { induced QTc-prolongation - results from a } \\
\text { controlled clinical trial. } \\
\text { Wieneke H, Conrads H, Wolstein } \\
\text { J, Breuckmann F, Gastpar M, Erbel } \\
\text { R, Scherbaum N. }\end{array}$ & $\begin{array}{l}\text { Committee for Proprietary Medicinal Products (CPMP). Points to } \\
\text { consider: the assessment of the potential for QT interval prolongation by } \\
\text { non-cardiovascular medicinal products. The European Agency for the } \\
\text { Evaluation of Medicinal Products. December } 1997 \text { [CPMP/986/96]. }\end{array}$ & $\begin{array}{c}1(4.5 \%) 431-450 \text { for males and } \\
451-470 \text { for females }\end{array}$ \\
\hline $\begin{array}{l}\text { QT-interval effects of methadone, } \\
\text { levomethadyl, and buprenorphine in a } \\
\text { randomized trial. } \\
\text { Wedam EF, Bigelow GE, Johnson RE, Nuzzo } \\
\text { PA, Haigney MC. }\end{array}$ & Author's modification of thresholds for abnormal prolongation of the QTC & $\begin{aligned} 13(23 \%) & >470 \mathrm{~ms} \text { for males } \\
& >490 \mathrm{~ms} \text { for females }\end{aligned}$ \\
\hline $\begin{array}{l}\text { Effects of methadone on QT-interval } \\
\text { dispersion. } \\
\text { Krantz MJ, Lowery CM, Martell } \\
\text { BA, Gourevitch MN, Arnsten JH }\end{array}$ & $\begin{array}{l}\text { Garson A Jr. How to measure the QT interval: what is normal? Am J } \\
\text { Cardiol 1993;72:14B-16. }\end{array}$ & $\begin{aligned} 19(16 \%) & >430 \text { for ms males } \\
& >450 \mathrm{~ms} \text { for females }\end{aligned}$ \\
\hline $\begin{array}{c}\text { Impact of methadone treatment on cardiac } \\
\text { repolarization and conduction in opioid } \\
\text { users. } \\
\text { Martell BA, Arnsten JH, Krantz } \\
\text { MJ, Gourevitch } M N\end{array}$ & $\begin{array}{l}\text { Authors defined a prolonged QTc interval as }>450 \mathrm{~ms} \text { for man and }>470 \\
\mathrm{~ms} \text { for women without stating reference. }\end{array}$ & $\begin{array}{l}14(20 \% \text { of } \operatorname{man} 2 \% \text { of women }) \\
\quad>450 \mathrm{~ms} \text { for man } \\
>470 \mathrm{~ms} \text { for females }\end{array}$ \\
\hline $\begin{array}{l}\text { Stereoselective Block of hERG Channel } \\
\text { by (S)-Methadone and QT Interval } \\
\text { Prolongation in CYP2B6 Slow Metabolizers } \\
\\
\text { CB Eap, S Crettol, J-S Rougier, J Schla "pfer, } \\
\text { L Sintra Grilo, J-J De'glon, J Besson, } M \\
\text { Croquette-Krokar, P-A Carrupt and H Abriel }\end{array}$ & $\begin{array}{l}\text { European Agency for the Evaluation of Medicinal Products. Committee } \\
\text { for Proprietary Medicinal Products. The assessment of the potential for } \\
\text { QT interval prolongation by non-cardiovascular medicinal products. } \\
\text { CPMP/986/96. http://www.emea.eu.int/pdfs/human/swp/098696en.pdf } \\
\text { (1997). }\end{array}$ & $\begin{aligned} 42(26 \%) & 430<\mathrm{QTc}<450 \\
16(9 \%) & >450 \text { for males } \\
& >470 \text { for females }\end{aligned}$ \\
\hline
\end{tabular}

Does methadone prolong QTC interval enough to evoke ventricular tachycardia? The point that all the researchers agreed upon was the importance of QTc prolongation over $500 \mathrm{~ms}$. Our research identified four studies that reported patients who did not have QTc intervals exceeding $500 \mathrm{~ms}$ $(19,22,25,27)$, but in one study, 6 of the 52 patients did have a QTc interval over $500 \mathrm{~ms}$ at some point in the study (20). Even though researchers have agreed that a QTc in- 
terval exceeding $500 \mathrm{~ms}$ is an important threshold, there were no cases of TdP. A possible explanation could be the fact that for registering events as rare as TdP, much larger study groups are necessary than the ones usually formed in MMT research studies (35). The largest study group we reviewed had 179 patients (30). Studies in our research that provided any data on TdP were clinical cases (31-33). All the studies with TdP events and data on QTc length found that in these clinical cases, TdP occurred among patients with a QTc interval over $600 \mathrm{~ms}(31,32)$.

Does the existence of other factors present among these patients have an effect on QTc interval length? Even though TdP appeared only among patients with QTc values significantly over the threshold known to be high risk for developing TdP, all of these patients also had 2 or more risk factors (31-33). The most often present risk factors in our research were dose of methadone $(23,25,27,28,29,30)$, co-medication $(22,23,27,30)$, and co-morbidity $(22,23$, $27)$, but also present were gender $(23,24,28)$, age $(23,28)$, misuse of illicit drugs $(25,29)$, therapy length $(28,29)$, and tobacco use (27).

The influence of methadone dose on QTc interval length was statistically demonstrated by uni- and multivariate analysis in certain studies from our research (table 2). The dose range in all of the studies from our research was 5-600 $\mathrm{mg} /$ day, whereas the most effective opioid dependence treatment dosage of methadone is $60-100 \mathrm{mg} /$ day (11). According to the Medicines and Health Care products Regulatory Agency (MHRA), a high dosage is considered anything above $100 \mathrm{mg} /$ day (26). Studies that gave detailed data on the dosage of methadone showed that all cases of QTc prolongation over $500 \mathrm{~ms}$, except one (24), were receiving more than $100 \mathrm{mg} /$ day of methadone $(24,28,29)$.

The often-present co-morbidities among MMT patients lead to considerable co-medication. HIV and HCV infections lead to electrolyte imbalance and to acute hepatitis that reduces the efficacy of methadone-metabolizing enzymes. Concomitant use of medicines that directly affect QTc interval or indirectly by interaction with methadonemetabolizing enzymes, thus increasing serum methadone level, could affect the length of QTc prolongation. A list of medicines that interact with MMT can be found online (35).

The reviewed data undoubtedly show the presence of prolonged QTc interval among some MMT patients, but it is hard to define how much of this QTc prolongation is the result of methadone activity and how much is the effect of other risk factors. Eap et al. pointed out that the presence of co-medication was similar between groups of patients with and without QTc prolongation, although uni- and multivariate analysis in their study showed a correlation between co-medication and QTc interval prolongation (30). An explanation for this could be found in the results of the latest genetic studies that showed inter-individual variations in the methadone metabolizing process and structure of cardiac ion channels $(30,36)$. A group of scientists led by Prof. Eap and coworkers researched stereo selectivity of methadoneinduced hERG channel blockage, and at the same time, they tested the hypothesis that CYP2B6 slow metabolizer status was connected with prolonged QTc interval (30). Out of 179 patients included in this study, 6\% had the CYP2B6 slow metabolizer genotype. The results of the study showed longer QTc intervals and higher plasma S-methadone concentrations in people with the CYP2B6 slow metabolizer genotype (439+/-25 ms VS 421+/-25 ms), whereas concentrations of plasma R-methadone were the same among all the patients. Higher incidence of borderline and prolonged QTc intervals (>450 ms) among patients with the CYP2B6 slow metabolizer genotype were also found. Prolonged QTc interval was noted among 3 of the 11 patients with this genotype (27\%), whereas QTc prolongation among patients with other genotypes was noted in 13 out of 168 cases (8\%). If we take into account borderline and prolonged QTc intervals, both parameters were found in 8 out of 11 patients with the CYP2B6 slow metabolizer genotype (73\%), and 50 out of 168 patients with other genotypes.

Another genetic study tested mutations on five genes that coded for subunits of cardiac ion channels among OMT patients identified with QTc $>500 \mathrm{~ms}$ (36). Out of 200 patients, 8 were recruited, and genetic testing revealed two heterozygous mutations for long QT syndrome (LQTS). The authors speculated that phenotypically silent or subclinical LQTS mutation carriers may become symptomatic in the presence of other risk factors. As LQTS carrier status is often unknown to the individual and clinician prior to the risk exposure, it could be directly manifested by syncopal and cardiac arrest episodes as had happened with these two patients from the study. During this study, 24-h ECG recordings were performed and showed diurnal fluctuations of the QTc interval in all patients; thus, the authors concluded that because of diurnal fluctuations of the QTc interval, there might have been missed cases of LQTS mutations among the rest of the patients who had a QTc $<500 \mathrm{~ms}$ in the assessment study.

The authors of both studies presented data on the frequency of these genetic mutations ( $6 \%$ of Caucasians with CYP2B6 SM status and prevalence of between 1/100 and $1 / 300$ of heterozygous mutation carriers in the general population), stating that these genotypes are of clinical relevance for methadone treatment.

To increase the safety of patients on MMT, the authors recommend that physicians obtain a careful screen for risk factors associated with long QT syndrome (23, 24, 31, 32), cardiac evaluation and systematic ECG especially among patients with a medical history of cardiac diseases, presence of congenital long QT syndrome and sudden cardiac death in families, a methadone dosage greater than $120 \mathrm{mg}$ (28) and after changes in therapy regime (27). They also mention that methadone's more favourable cost profile and efficacy will still keep it as a first line of opiate addiction treatment $(22,24,30)$.

Undoubtedly, improvement in the resocialization process as a final step of opiate addiction treatment leads to a reduction in methadone dose and finally exclusion from methadone treatment, thus erasing any potential effect of methadone on QTc interval. 
Table 2: Research papers that shows statistically significant risk factors.

\begin{tabular}{|c|c|c|}
\hline \multirow{4}{*}{$\begin{array}{l}\text { Effects of methadone on QT- } \\
\quad \text { interval dispersion. } \\
\text { Krantz MJ, Lowery CM, Martell } \\
\text { BA, Gourevitch MN, Arnsten JH. }\end{array}$} & UNIVARIATE ANALYSIS & $\begin{array}{l}\text { Baseline clinical variables tested for association with QT dispersion were age, sex, } \\
\text { taking drugs that affect cardiac repolarization or methadone metabolism, self- } \\
\text { reported cardiovascular disease, use of cocaine at baseline, and infection with human } \\
\text { immunodeficiency virus or hepatitis C. Of these variables, the only one associated with the } \\
\text { magnitude of QT dispersion at baseline was self-reported cardiovascular disease ( } 42.1 \mathrm{vs} \\
31.7 \text { msec, p }<0.01) \text {. At } 6 \text { months none of these variables remained significantly associated } \\
\text { with absolute QT dispersion. } \\
\text { The same clinical variables were then tested for association with the magnitude of change } \\
\text { in QT dispersion over } 6 \text { months and only concurrent antidepressant therapy was associated } \\
\text { with a greater increase in QT dispersion }(20 \text { vs } 8.5 \mathrm{msec}, \mathrm{p}=0.04) \text {. }\end{array}$ \\
\hline & BIVARIATE ANALYSIS & N/A \\
\hline & MULTIVARIATE ANALYSIS & N/A \\
\hline & STATISTICAL TEST USED & $\begin{array}{l}\text { Univariate associations were tested using Pearson correlation coefficients for continuous } \\
\text { independent variables and the Student t test for categoric independent variables. } \\
\text { Multivariate associations with the magnitude of the change in QTc interval were tested } \\
\text { using linear regression models. }\end{array}$ \\
\hline \multirow{4}{*}{$\begin{array}{l}\text { Impact of methadone treatment } \\
\text { on cardiac repolarization and } \\
\text { conduction in opioid users. } \\
\text { Martell BA, Arnsten JH, Krantz } \\
\text { MJ, Gourevitch MN }\end{array}$} & UNIVARIATE ANALYSIS & $\begin{array}{l}\text { Variables associated with a longer QTc interval at baseline were older age }(\mathrm{r}=0.25, \mathrm{p}= \\
0.001) \text {, female gender (women vs men, } 426 \mathrm{vs} 414 \mathrm{~ms} ; \mathrm{p}=0.001) \text {, self-reported cardiac } \\
\text { disease ( } 434 \mathrm{vs} 416 \mathrm{~ms}, \mathrm{p}=0.03) \text {; use of antidepressants }(430 \mathrm{vs} 418 \mathrm{~ms}, \mathrm{p}<0.0001) \text { and } \\
\text { calcium antagonists }(432 \mathrm{vs} 417 \mathrm{~ms}, \mathrm{p}=0.07) \text {; hepatitis } \mathrm{C} \text { infection }(423 \mathrm{vs} 413 \mathrm{~ms}, \mathrm{p}=0.08) \\
\text { and HIV infection ( } 423 \mathrm{vs} 417 \mathrm{~ms}, \mathrm{p}=0.08) \text {. } \\
\text { Only the methadone dose was significantly associated with the magnitude of the QTc } \\
\text { increase from baseline to } 6 \text { months }(\mathrm{r}=0.18, \mathrm{p}=0.03) \text {. }\end{array}$ \\
\hline & BIVARIATE ANALYSIS & $\mathrm{N} / \mathrm{A}$ \\
\hline & MULTIVARIATE ANALYSIS & $\begin{array}{l}\text { Controlling for all factors associated with the baseline QTc interval and use of heroin, } \\
\text { cocaine, and/or benzodiazepines, factors that were associated with greater QTc } \\
\text { prolongation from baseline to } 6 \text { months, included male gender, HIV infection, and } \\
\text { methadone dose. } \\
\text { At the } 12 \text {-month follow-up only the } 12 \text {-month methadone dose remained marginally } \\
\text { associated with the magnitude of the QTc increase }(\mathrm{p}=0.08) \text {. }\end{array}$ \\
\hline & STATISTICAL TEST USED & $\begin{array}{l}\text { Univariate associations were tested using Pearson's correlation coefficients for continuous } \\
\text { variables and the Student } t \text { test for categorical variables. } \\
\text { Multivariate associations with the magnitude of the QTc interval or change in QTc interval } \\
\text { were tested using linear regression models with } p<0.10 \text { as the model entry criterion. }\end{array}$ \\
\hline \multirow{4}{*}{$\begin{array}{l}\text { QT interval prolongation: } \\
\text { prevalence, risk factors and } \\
\text { pharmacovigilance data among } \\
\text { methadone-treated patients in } \\
\text { France. } \\
\text { Perrin-Terrin A, Pathak } A \text {, } \\
\text { Lapeyre-Mestre } M .\end{array}$} & UNIVARIATE ANALYSIS & N/A \\
\hline & BIVARIATE ANALYSIS & N/A \\
\hline & MULTIVARIATE ANALYSIS & $\begin{array}{l}\text { In the multiple linear regression, QTc length was associated }(\mathrm{r} 2=0.74) \text { with history of heart } \\
\text { disease }[\mathrm{b}=251.3(\mathrm{SD} 123.4), \mathrm{P}=0.04] \text {, tobacco use }[\mathrm{b}=234.5(\mathrm{SD} 74.9), \mathrm{P}=0.003] \text {, and } \\
\text { QT-prolonging drugs }[\mathrm{b}=275.5(\mathrm{SD} 78.2), \mathrm{P}=0.001] . \\
\text { QT dispersion was associated }(\mathrm{r} 2=0.73) \text { with history of heart disease }[\mathrm{b}=62.8(\mathrm{SD} 26.6), \mathrm{P} \\
=0.02] \text {, recent increase in methadone dose }[\mathrm{b}=68.5(\mathrm{SD} 21.6), \mathrm{P}=0.003], \text { tobacco use }[\mathrm{b}= \\
50.1(\mathrm{SD} 16.1), \mathrm{P}=0.003] \text {, and QT-prolonging drugs }[\mathrm{b}=60.8(\mathrm{SD} 74.9), \mathrm{P}<0.001] \text {. }\end{array}$ \\
\hline & STATISTICAL TEST USED & Multiple linear regression \\
\hline \multirow{4}{*}{$\begin{array}{l}\text { Methadone maintenance, QTc and } \\
\text { torsade de pointes: who needs an } \\
\text { electrocardiogram and what is the } \\
\text { prevalence of QTc prolongation? } \\
\text { Mayet S, Gossop M, Lintzeris N, } \\
\text { Markides V, Strang J. }\end{array}$} & UNIVARIATE ANALYSIS & N/A \\
\hline & BIVARIATE ANALYSIS & $\begin{array}{l}\text { Bivariate analysis found no factor independently associated with QT length or QTc } \\
\text { prolongation. }\end{array}$ \\
\hline & MULTIVARIATE ANALYSIS & $\begin{array}{l}\text { Multivariate analysis, via multiple linear backward regression, investigated the relationship } \\
\text { between QTc length and the following covariates: prescribed methadone daily dose (log } \\
\text { base } 10) \text {, stimulant use (illicit and prescribed), benzodiazepine use (illicit and prescribed), } \\
\text { alcohol use, heroin use, tobacco use, cannabis use, gender and age. Total daily methadone } \\
\text { dose ( } \mathrm{b}=0.318, \mathrm{P}=0.003) \text { and use of stimulants (cocaine or amphetamines) }(\mathrm{b}=0.213, \mathrm{P}= \\
0.043 \text { ) were found to be predictive of QTc length. Binary logistic regression was conducted } \\
\text { investigating QTc prolongation did not reveal a statistically significant association. }\end{array}$ \\
\hline & STATISTICAL TEST USED & Multiple linear backward regression \\
\hline \multirow{4}{*}{$\begin{array}{l}\text { Prevalence and clinical relevance } \\
\text { of corrected QT interval } \\
\text { prolongation during methadone } \\
\text { and buprenorphine treatment: a } \\
\text { mortality assessment study. } \\
\text { Anchersen } K \text {, Clausen T, Gossop M, } \\
\quad \text { Hansteen } V, \text { Waal H. }\end{array}$} & UNIVARIATE ANALYSIS & $\begin{array}{l}\text { Dose of methadone }\left(0.373^{*}\right) \mathrm{P}=0.001 \mathrm{~b}=0.365 \\
\text { Gender }\left(0.080^{*}\right) \mathrm{P}=0.295 \mathrm{~b}=0.079 \\
\text { Age (years) }\left(0.134^{*}\right) \mathrm{P}=0.080 \mathrm{~b}=0.115 \\
\text { Time in treatment }\left(0.144^{*}\right) \mathrm{P}=0.058 \mathrm{~b}=0.027\end{array}$ \\
\hline & BIVARIATE ANALYSIS & N/A \\
\hline & MULTIVARIATE ANALYSIS & $\begin{array}{l}\text { Dose of methadone B } 0.367^{* *} 95 \% \text { CI of B } 0.22-0.51 \mathrm{P}=0.001 \\
\text { Gender B } 5.988^{* *} 95 \% \text { CI of B }-4.62-16.59 \mathrm{P}=0.226 \\
\text { Age (years) B } 0.569 * 95 \% \text { CI of B }-0.14-1.38 \mathrm{P}=0.137 \\
\text { Time in treatment B } 0.029^{* *} 95 \% \text { CI of B }-0.14-0.20 \mathrm{P}=0.410\end{array}$ \\
\hline & STATISTICAL TEST USED & $\begin{array}{l}\text { Pearson's correlation* } \\
\text { Multiple linear regression** } \\
\text { A positive correlation was found between QTc interval and dose of methadone, both in } \\
\text { Pearson's correlation }(\mathrm{r}=0.37, \mathrm{P}=0.01) \text { and in the multiple linear regression analysis }(\mathrm{B}= \\
0.37, \mathrm{P}=0.01) \text {. No statistically significant correlation was detected between QTc interval } \\
\text { and time in treatment, age or gender }\end{array}$ \\
\hline
\end{tabular}




\begin{tabular}{|c|c|c|}
\hline \multirow{4}{*}{$\begin{array}{l}\text { Corrected-QT intervals as related } \\
\text { to methadone dose and serum } \\
\text { level in methadone maintenance } \\
\text { treatment (MMT) patients: a } \\
\quad \text { cross-sectional study. } \\
\text { Peles E, Bodner G, Kreek MJ, Rados } \\
\quad \text { V, Adelson M. }\end{array}$} & UNIVARIATE ANALYSIS & N/A \\
\hline & BIVARIATE ANALYSIS & N/A \\
\hline & MULTIVARIATE ANALYSIS & $\begin{array}{l}\text { QTc correlated significantly with duration in MMT }(\mathrm{r}=0.24, \mathrm{P}=0.005) \text {, but only as a trend } \\
\text { with methadone daily doses }(\mathrm{r}=0.13, \mathrm{P}=0.1) \text {, and not at all with serum methadone levels } \\
(\mathrm{r}=0.01, \mathrm{P}=1) \text {. QTc intervals correlated significantly with methadone doses in cocaine } \\
\text { abuse patients }(\mathrm{n}=31), \mathrm{r}=0.4, \mathrm{P}=0.03) \text {, but not in the } 107 \text { 'non-cocaine-abuse' patients ( } \mathrm{r} \\
=0.04, \mathrm{P}=0.4) \text {. }\end{array}$ \\
\hline & STATISTICAL TEST USED & $\begin{array}{l}\text { The correlation between QTc interval and methadone (dose and duration) was determined } \\
\text { using Pearson's correlation coefficients Continuous variables of differences between groups } \\
\text { were analyzed using oneway analysis of variance (ANOVA) and results are presented as } \\
\text { mean standard deviation. Categorical variables were presented as proportions (\%). }\end{array}$ \\
\hline \multirow{4}{*}{$\begin{array}{l}\text { QTc interval prolongation in } \\
\text { patients on long-term methadone } \\
\text { maintenance therapy. (1.14) } \\
\text { Maremmani I, Pacini M, Cesaroni } \\
\text { C, Lovrecic M, Perugi G, Tagliamonte } \\
\text { A. }\end{array}$} & UNIVARIATE ANALYSIS & No correlation was found between QTc values and methadone doses or gender. \\
\hline & BIVARIATE ANALYSIS & N/A \\
\hline & MULTIVARIATE ANALYSIS & $\mathrm{N} / \mathrm{A}$ \\
\hline & STATISTICAL TEST USED & Pearson's correlation \\
\hline \multirow{4}{*}{$\begin{array}{l}\text { Stereoselective Block of hERG } \\
\text { Channel by (S)-Methadone and } \\
\text { QT Interval Prolongation in } \\
\text { CYP2B6 Slow Metabolizers } \\
\text { CB Eap, S Crettol, J-S Rougier, } \\
\text { J Schla"pfer, L Sintra Grilo, J-J } \\
\text { De'glon, J Besson, } M \text { Croquette- } \\
\text { Krokar, P-A Carrupt and H Abriel }\end{array}$} & UNIVARIATE ANALYSIS & $\begin{array}{l}\text { Univariate analysis between } \mathrm{QTc} \text { interval at trough and several risk factors indicated that } \\
\text { trough }(\mathrm{R}, \mathrm{S})-\text { methadone concentrations }(\mathrm{r}=0.31, \mathrm{r} 2=0.097, \mathrm{P}=0.00005) \text {, use of co- } \\
\text { medications }(\mathrm{r}=0.18, \mathrm{r} 2=0.034, \mathrm{P}=0.01) \text {, methadone daily dose }(\mathrm{r}=0.19, \mathrm{r} 2=0.036, \mathrm{P} \\
=0.01), \mathrm{CYP} \mathrm{B} 6 \mathrm{SM} \text { status }(\mathrm{r}=0.18, \mathrm{r} 2=0.032, \mathrm{P}=0.02) \text {, and serum calcium }(\mathrm{r}=-0.15, \mathrm{r} 2 \\
=0.023, \mathrm{P}=0.04) \text {, were predictive of the QTc interval duration. Other variables, such as } \\
\text { gender }(\mathrm{P}=0.35) \text {, age }(\mathrm{P}=0.28) \text {, serum potassium }(\mathrm{P}=0.42) \text {, cocaine }(\mathrm{P}=0.45) \text { and alcohol } \\
(\mathrm{P}=0.51) \text { consumption, were not predictive of the } \mathrm{QTc} \text { interval duration. }\end{array}$ \\
\hline & BIVARIATE ANALYSIS & N/A \\
\hline & MULTIVARIATE ANALYSIS & $\begin{array}{l}\text { Multivariate analysis yielded a model including trough }(\mathrm{R}, \mathrm{S}) \text {-methadone concentrations } \\
(\mathrm{P}<0.0005) \text {, hypocalcemia }(<2.2 \mathrm{mmol} / \mathrm{l} ; \mathrm{P}=0.02) \text {, use of co-medication }(\mathrm{P}=0.03) \text {, and CYP2B6 } \\
\text { status }(\mathrm{P}=0.05) \text { with a determination coefficient }(\mathrm{r} 2) \text { of } 0.17(\mathrm{n}=179 ; \mathrm{P}=0.00005) \text {. }\end{array}$ \\
\hline & STATISTICAL TEST USED & Pearson correlation, regression, $\mathrm{X}^{2}$ \\
\hline
\end{tabular}

Table 3: List of all researches from Results.

\begin{tabular}{|c|c|c|}
\hline \multirow{4}{*}{$\begin{array}{l}\text { QT interval prolongation: } \\
\text { prevalence, risk factors and } \\
\text { pharmacovigilance data } \\
\text { among methadone-treated } \\
\text { patients in France. }\end{array}$} & Journal & Fundamental \& clinical pharmacology \\
\hline & Type of Study & Cross-Sectional Study \& Retrospective study \\
\hline & Number & 42-550 (in adverse drug reactions (ADRs) spontaneously reported with methadone from 1996 to 2007 \\
\hline & $\begin{array}{l}\text { Other Medications } \\
\text { Evaluated or Present }\end{array}$ & Amisulpride, Mianserine, Alimemazine, Cyamemazine, Fluoxetine \\
\hline \multirow[t]{4}{*}{$\begin{array}{l}\text { Perrin-Terrin A, Pathak A, } \\
\text { Lapeyre-Mestre } M .\end{array}$} & $\begin{array}{l}\text { Other Drugs of Abuse } \\
\text { Evaluated }\end{array}$ & Codeine, Tobacco, Heroin, Amphetamine, Opiates, Alcohol \\
\hline & $\begin{array}{l}\text { Other Medical Conditions } \\
\text { Evaluated }\end{array}$ & $\begin{array}{l}\text { Depression, Insomnia, Anxiety Psychosis or personality disorders Hepatitis C HIV Cardiac arrhythmia } \\
\text { Arterial Hypertension }\end{array}$ \\
\hline & Major Findings & $\begin{array}{l}\text { 4. QTc prolongation in Cross Sectional Study } 5 \text { QTc prolongations (3TdP) and seven sudden cardiac } \\
\text { deaths not correlated with Methadone overdose in retrospective study. }\end{array}$ \\
\hline & $\begin{array}{l}\text { Notes, Including } \\
\text { Limitations }\end{array}$ & Small study group in Cross Sectional Study \\
\hline \multirow{8}{*}{$\begin{array}{l}\text { Methadone maintenance, } \\
\text { QTc and torsade de } \\
\text { pointes: who needs an } \\
\text { electrocardiogram and what } \\
\text { is the prevalence of QTc } \\
\text { prolongation? } \\
\text { Mayet } S \text {, Gossop } M \text {, } \\
\text { Lintzeris } N \text {, Markides } V \text {, } \\
\text { Strang J. }\end{array}$} & Journal & Drug and alcohol review \\
\hline & Type of Study & Cross-Sectional stady \\
\hline & Number & 155 \\
\hline & $\begin{array}{l}\text { Other Medications } \\
\text { Evaluated or Present }\end{array}$ & $\begin{array}{l}\text { Citalopram, Zopiclone, Salbutamol, Quetiapine, Chlorpromazine, Temazepam, Dexamphetamine, } \\
\text { Olanzapine }\end{array}$ \\
\hline & $\begin{array}{l}\text { Other Drugs of Abuse } \\
\text { Evaluated }\end{array}$ & Cocaine, Tobacco, Heroin, Benzodiazepine, Alcohol \\
\hline & $\begin{array}{l}\text { Other Medical Conditions } \\
\text { Evaluated }\end{array}$ & Hepatitis C \\
\hline & Major Findings & $\begin{array}{l}57.4 \%(\mathrm{n}=89) \text { fulfilled MHRA criteria for ECG monitoring, QTc prolongation prevalence was } 18.1 \% \\
\text { with NO ,clinically significant }{ }^{c} \text { QTc prolongation }>500 \mathrm{~ms} \text { or torsade de pointes known to be present }\end{array}$ \\
\hline & $\begin{array}{l}\text { Notes, Including } \\
\text { Limitations }\end{array}$ & \\
\hline
\end{tabular}




\begin{tabular}{|c|c|c|}
\hline \multirow{4}{*}{$\begin{array}{l}\text { Prevalence and clinical } \\
\text { relevance of corrected } \\
\text { QT interval prolongation } \\
\text { during methadone and } \\
\text { buprenorphine treatment: a } \\
\text { mortality assessment study. }\end{array}$} & Journal & Addiction (Abingdon, England) \\
\hline & Type of Study & Mortality assessment study \\
\hline & Number & 173 patients on methadone \\
\hline & $\begin{array}{l}\text { Other Medications } \\
\text { Evaluated or Present }\end{array}$ & N/A \\
\hline \multirow{4}{*}{$\begin{array}{l}\text { Anchersen } K, \text { Clausen T, } \\
\text { Gossop M, Hansteen V, } \\
\text { Waal H. }\end{array}$} & $\begin{array}{l}\text { Other Drugs of Abuse } \\
\text { Evaluated }\end{array}$ & N/A \\
\hline & $\begin{array}{l}\text { Other Medical Conditions } \\
\text { Evaluated }\end{array}$ & N/A \\
\hline & Major Findings & $\begin{array}{l}\text { 4.6\% }(\mathrm{n}=8) \text { had a QTc above } 500 \text { milliseconds; } 15 \%(\mathrm{n}=26) \text { had a QTc interval above } 470 \text { milliseconds; } \\
\text { and } 28.9 \%(\mathrm{n}=50) \text { had a QTc above } 450 \text { milliseconds.A positive dose-dependent association was } \\
\text { identified between QTc length and dose of methadone, and all patients with a QTc above } 500 \\
\text { milliseconds were taking methadone doses of } 120 \mathrm{mg} \text { or more. OMT patient mortality, where QTc } \\
\text { prolongation could not be excluded as the cause of death, was } 0.06 / 100 \text { patient-years. Only one death } \\
\text { among } 3850 \text { OMT initiations occurred within the first month of treatment. }\end{array}$ \\
\hline & $\begin{array}{l}\text { Notes, Including } \\
\text { Limitations }\end{array}$ & \\
\hline \multirow{8}{*}{$\begin{array}{l}\text { Heterogeneous impact of } \\
\text { methadone on the QTc } \\
\text { interval: what are the } \\
\text { practical implications? }\end{array}$} & Journal & Journal of addictive diseases \\
\hline & Type of Study & Prospective Cohort Study \\
\hline & Number & 151 \\
\hline & $\begin{array}{l}\text { Other Medications } \\
\text { Evaluated or Present }\end{array}$ & N/A \\
\hline & $\begin{array}{l}\text { Other Drugs of Abuse } \\
\text { Evaluated }\end{array}$ & $\mathrm{N} / \mathrm{A}$ \\
\hline & $\begin{array}{l}\text { Other Medical Conditions } \\
\text { Evaluated }\end{array}$ & N/A \\
\hline & Major Findings & $\begin{array}{l}\text { The proportion exceeding } 450 \mathrm{msec} \text { increased from } 7 \% \text { at baseline to } 19 \% \text { at } 6 \text { months; those exceeding } \\
500 \mathrm{msec} \text { increased from } 0 \% \text { to } 2 \% \text {. Although } 18 \% \text { of subjects had an increase in QTc of } 30 \mathrm{msec} \text {, only } \\
3 \% \text { had an increase exceeding } 60 \mathrm{msec} \text {. }\end{array}$ \\
\hline & $\begin{array}{l}\text { Notes, Including } \\
\text { Limitations }\end{array}$ & $\begin{array}{l}\text { Critical QTc prolongation (exceeding } 500 \mathrm{msec} \text { or increases exceeding } 60 \mathrm{msec} \text { ) occurred infrequently. } \\
\text { This highlights the heterogeneity of QTc interval changes and measurement variability but also implies } \\
\text { that electrocardiography screening among opioid dependent patients would only occasionally require } \\
\text { methadone discontinuation. }\end{array}$ \\
\hline \multirow{8}{*}{$\begin{array}{l}\text { Corrected-QT intervals } \\
\text { as related to methadone } \\
\text { dose and serum level in } \\
\text { methadone maintenance } \\
\text { treatment (MMT) patients: } \\
\text { a cross-sectional study. } \\
\text { Peles } E, \text { Bodner } G, \underline{\text { Kreek } M J}, \\
\underline{\text { Rados } V, \text { Adelson } M .}\end{array}$} & Journal & Addiction (Abingdon, England) \\
\hline & Type of Study & Cross-sectional study \\
\hline & Number & 138 \\
\hline & $\begin{array}{l}\text { Other Medications } \\
\text { Evaluated or Present }\end{array}$ & $\begin{array}{l}\text { Propanolol, Aspirin, Mirtazapime sodium, Valproate Acetylsalicylic Acid Simvastatin, Ramipril, } \\
\text { Isosorbide Mononitrate Clonazepam, Fluoxetine Thyroxin sodium, Salbutamol, Enoxaparin, } \\
\text { Haloperidol, Biperiden }\end{array}$ \\
\hline & $\begin{array}{l}\text { Other Drugs of Abuse } \\
\text { Evaluated }\end{array}$ & Benzodiazepine, Opiate Cannabis Cocaine Amphetamine \\
\hline & $\begin{array}{l}\text { Other Medical Conditions } \\
\text { Evaluated }\end{array}$ & HIV, HVB, HVC \\
\hline & Major Findings & $\begin{array}{l}\text { Mean methadone dose was } 170.9+/-50.3 \mathrm{mg} / \text { day and mean serum methadone level was } 708.2+/-363.1 \\
\text { ng/ml. Methadone dose and serum levels did not correlate with QTc. Three patients had QTc intervals } \\
\text { above } 500 \mathrm{~ms} \text { (,prolonged'). After } 2+/-0.4 \text { years of follow-up, two patients died; they were two of three } \\
\text { patients with very prolonged QTc. Causes of death were not attributed to cardiac origin. }\end{array}$ \\
\hline & $\begin{array}{l}\text { Notes, Including } \\
\text { Limitations }\end{array}$ & $\begin{array}{l}\text { Methadone maintenance is generally safe; however, the possible toxicity of high dose (> } 120 \mathrm{mg} / \text { day) } \\
\text { should be monitored for QTc }\end{array}$ \\
\hline \multirow{8}{*}{$\begin{array}{l}\text { QTc interval prolongation } \\
\text { in patients on long-term } \\
\text { methadone maintenance } \\
\text { therapy. } \\
\text { Maremmani I, Pacini } M \text {, } \\
\text { Cesaroni } C, \text { Lovrecic } M \text {, } \\
\text { Perugi } G, \text { Tagliamonte } A .\end{array}$} & Journal & European addiction research \\
\hline & Type of Study & Prospective study \\
\hline & Number & 83 \\
\hline & $\begin{array}{l}\text { Other Medications } \\
\text { Evaluated or Present }\end{array}$ & N/A \\
\hline & $\begin{array}{l}\text { Other Drugs of Abuse } \\
\text { Evaluated }\end{array}$ & N/A \\
\hline & $\begin{array}{c}\text { Other Medical Conditions } \\
\text { Evaluated }\end{array}$ & N/A \\
\hline & Major Findings & $\begin{array}{l}\text { Eighty-three percent of the subjects had a more prolonged QT df (QT df is the difference between QTc } \\
\text { and standardized values and it corresponds to the gap between an individual's QT and the expected for } \\
\text { healthy subjects) than the reference values for persons of the same sex and age. Only } 2 \text { patients displayed } \\
\text { a QTc interval of }>500 \mathrm{~ms} \text {. No correlation emerged between QTc values and methadone dosages. }\end{array}$ \\
\hline & $\begin{array}{l}\text { Notes, Including } \\
\text { Limitations }\end{array}$ & \\
\hline
\end{tabular}




\begin{tabular}{|c|c|c|}
\hline \multirow{8}{*}{$\begin{array}{l}\text { Levo-alpha-acetylmethadol } \\
\text { (LAAM) induced QTc- } \\
\text { prolongation - results from } \\
\text { a controlled clinical trial. } \\
\text { Wieneke H, Conrads } \\
\underline{\text { H, Wolstein J, Breuckmann }} \\
\underline{\text { F, Gastpar M, Erbel }} \\
\underline{\mathrm{R}, \text { Scherbaum N. }}\end{array}$} & Journal & European Journal of Medical Research \\
\hline & Type of Study & Experimental study \\
\hline & Number & 22 in methadone group \\
\hline & $\begin{array}{l}\text { Other Medications } \\
\text { Evaluated or Present }\end{array}$ & An patient with abnormal QTc interval received tricyclic antidepressant. \\
\hline & $\begin{array}{l}\text { Other Drugs of Abuse } \\
\text { Evaluated }\end{array}$ & $\begin{array}{l}\text { Urine drug screening revealed continuous use of cocaine during the study in one patient with abnormal } \\
\text { QTc intervals. }\end{array}$ \\
\hline & $\begin{array}{l}\text { Other Medical Conditions } \\
\text { Evaluated }\end{array}$ & Subjects with known cardiac disease were excluded \\
\hline & Major Findings & $\begin{array}{l}\text { No significant change in QTc interval in methadone group }(0.406 \mathrm{~s} \pm 0.029 \mathrm{~s} \text { at run-in versus } 0.405 \mathrm{~s} \pm \\
0.025 \mathrm{~s} \text { at } 24 \text { weeks) }\end{array}$ \\
\hline & $\begin{array}{l}\text { Notes, Including } \\
\text { Limitations }\end{array}$ & $\begin{array}{l}84 \text { subjects were initially enrolled in the study and } 53 \text { complete ECG data sets could be obtained. It } \\
\text { reflects the difficulties in conducting clinical studies in this patient group and has also been reported } \\
\text { from other studies }\end{array}$ \\
\hline \multirow{8}{*}{$\begin{array}{l}\text { QT-interval effects of } \\
\text { methadone, levomethadyl, } \\
\text { and buprenorphine in a } \\
\text { randomized trial. } \\
\text { Wedam EF, Bigelow } \\
\text { GE, Johnson RE, Nuzzo } \\
\text { PA, Haigney } M C .\end{array}$} & Journal & Archives of internal medicine \\
\hline & Type of Study & Experimental study (Randomized double-blind clinical trial) \\
\hline & Number & $\begin{array}{l}\text { Analyses were limited to the } 154 \text { patients and among them } 55 \text { in methadone group started the study and } \\
32 \text { finished it }\end{array}$ \\
\hline & $\begin{array}{l}\text { Other Medications } \\
\text { Evaluated or Present }\end{array}$ & One participant used Erythromicin (potentially prolonging the QT) \\
\hline & $\begin{array}{c}\text { Other Drugs of Abuse } \\
\text { Evaluated }\end{array}$ & $\mathrm{N} / \mathrm{A}$ \\
\hline & $\begin{array}{c}\text { Other Medical Conditions } \\
\text { Evaluated }\end{array}$ & N/A \\
\hline & Major Findings & $\begin{array}{l}\text { Using the categorical definition for QTc prolongation of more than } 470 \text { milliseconds for males and more } \\
\text { than } 490 \text { milliseconds for females prolongation occurred among } 23 \% \text { of the methadone group }(\mathrm{P}<.001) \text {. } \\
\text { An absolute QTc value of more than } 500 \mathrm{~ms} \text { occurred among } 6 \text { of } 52 \text { individuals in the methadone group } \\
(\mathrm{P}<.001) \text { at some point during the trial By stringent standard of an increase in QTc from baseline of more } \\
\text { than } 60 \text { milliseconds at any time during the study } 12 \% \text { of subjects treated with methadone }(\mathrm{OR}, 8.4 ; 95 \% \\
\mathrm{CI}, 1.9-36.4) \text { showed this increase }\end{array}$ \\
\hline & $\begin{array}{l}\text { Notes, Including } \\
\text { Limitations }\end{array}$ & $\begin{array}{l}\text { Female sex has been associated with considerably higher risks for QT prolongation and TdP but in the } \\
\text { present study there was no significant difference between men and women with respect to prolongation } \\
\text { more than } 60 \text { milliseconds from baseline }(\mathrm{P}=.68) \text {. }\end{array}$ \\
\hline \multirow{8}{*}{$\begin{array}{l}\text { Effects of methadone on } \\
\text { QT-interval dispersion. } \\
\text { Krantz MJ, Lowery } \\
\text { CM, Martell BA, Gourevitch } \\
\text { MN, Arnsten JH. }\end{array}$} & Journal & Pharmacotherapy \\
\hline & Type of Study & Prospective cohort study \\
\hline & Number & 118 patients who were newly admitted to the facility \\
\hline & $\begin{array}{l}\text { Other Medications } \\
\text { Evaluated or Present }\end{array}$ & $\begin{array}{l}\text { Isoniazid Antiretroviral agents AntidepressantsDiuretics Calcium channel blockers } \\
\text { Beta blockers Phenytoin }\end{array}$ \\
\hline & $\begin{array}{l}\text { Other Drugs of Abuse } \\
\text { Evaluated }\end{array}$ & Cocain, Alcohol (> 10 drinks a week) \\
\hline & $\begin{array}{c}\text { Other Medical Conditions } \\
\text { Evaluated }\end{array}$ & Hepatitis C, HIV Cardiovascular disease Hypokalemia \\
\hline & Major Findings & Methadone modestly but statistically significantly increased both QTc interval and QT dispersion. \\
\hline & $\begin{array}{l}\text { Notes, Including } \\
\text { Limitations }\end{array}$ & $\begin{array}{l}\text { Baseline clinical variables tested for association with QT dispersion were age, sex, taking drugs that affect } \\
\text { cardiac repolarization or methadone metabolism, self-reported cardiovascular disease, use of cocaine at } \\
\text { baseline, and infection with human immunodeficiency virus or hepatitis } C \text { and the only one associated with } \\
\text { the magnitude of QT dispersion at baseline was self-reported cardiovascular disease ( } 42.1 \text { vs } 31.7 \mathrm{msec} \text {, } \\
\text { p }<0.01) \text {. The same clinical variables were then tested for association with the magnitude of change in QT } \\
\text { dispersion over } 6 \text { months. Only concurrent antidepressant therapy was associated with a greater increase in } \\
\text { QT dispersion ( } 20 \text { vs } 8.5 \mathrm{msec}, \mathrm{p}=0.04) \text {. }\end{array}$ \\
\hline
\end{tabular}

\section{REFERENCES:}

1. World Health Organization. WHO model list of essential medicines, http://www.who.int/medicines/publications/essentialmedicines/en/index.html (2005).

2. U.S. Food and Drug Administration. Methadone Hydrolcholoride. FDA alert [11/2006]: death, narcotic overdose, and serious cardiac arrhythmias. [updated 2008 August 23; cited 2006 Nov 29] Available from: http:// www.fda. gov/cder/drug/advisory/methadone.htm
3. Cruciani RA. Methadone: to ECG or not to ECG...That is still the question. J Pain Symptom Manage. 2008 Nov;36(5):545-52.

4. Kristensen, K, Christensen, C, The mu1, mu2, delta, kappa opioid receptor binding profiles of methadone stereoisomers and morphine. Life Sci. 56, L45-L50 (1995).

5. Gorman, A.L., Elliott.The d- and 1-isomers of methadone bind to the non-competitive site on the N-meth- 


\begin{tabular}{|c|c|c|}
\hline \multirow{8}{*}{$\begin{array}{l}\text { Impact of methadone } \\
\text { treatment on cardiac } \\
\text { repolarization and } \\
\text { conduction in opioid users. } \\
\text { Martell BA, Arnsten } \\
\underline{M}, \underline{\text { Krantz } M J}, \text { Gourevitch }\end{array}$} & Journal & American Journal of Cardiology \\
\hline & Type of Study & Prospective cohort study \\
\hline & Number & $\begin{array}{l}\text { At baseline } 233 \text { participants, ECG obtained from } 149 \text { after } 6 \text { months study period and } 97 \text { patients had all } \\
\text { three ECG's done after } 12 \text { months; } 108 \text { participants had ECG at baseline and } 12 \text { months (without ECG } \\
\text { recording after } 6 \text { months period) }\end{array}$ \\
\hline & $\begin{array}{l}\text { Other Medications } \\
\text { Evaluated or Present }\end{array}$ & $\begin{array}{l}\text { Isoniazid, Antiretroviral agents, Antidepressants, Diuretics, Calcium channel blockers, Beta blockers, } \\
\text { Phenytoin }\end{array}$ \\
\hline & $\begin{array}{l}\text { Other Drugs of Abuse } \\
\text { Evaluated }\end{array}$ & Cocain, Alcohol (>10 drinks a week), Benzodiaze-pine \\
\hline & $\begin{array}{c}\text { Other Medical Conditions } \\
\text { Evaluated }\end{array}$ & Hepatitis C, HIV Cardiovascular disease, Hypokalemia \\
\hline & Major Findings & $\begin{array}{l}\text { The QTc interval increased significantly from baseline at both time intervals but the mean difference } \\
\text { in QTc interval from } 6 \text { to } 12 \text { months was not significant }(\mathrm{p}=0.4) \text {. At baseline, } 5 \text { subjects }(3 \%) \text { had } \\
\text { prolonged QTc intervals, defined as }>450 \mathrm{~ms} \text { for men }(\mathrm{n}=3) \text { and }>470 \mathrm{~ms} \text { for women }(\mathrm{n}=2) \text {. At } \\
6 \text {-month follow up, } 18 \text { subjects }(13 \% \text { of men and } 11 \% \text { of women }) \text { had prolonged QTc intervals, and } 2 \\
\text { patients had QTc intervals of }>500 \mathrm{~ms} \text {. At } 12 \text { months, } 14 \text { subjects }(20 \% \text { of men and } 2 \% \text { of women }) \text { had } \\
\text { prolonged QTc intervals, and } 2 \text { patients had QTc intervals of }>500 \mathrm{~ms} \text {. }\end{array}$ \\
\hline & $\begin{array}{l}\text { Notes, Including } \\
\text { Limitations }\end{array}$ & $\begin{array}{l}\text { At the } 12 \text {-month follow-up visit, a subset of } 44 \text { patients had same-day serum methadone concentrations } \\
\text { measured at trough (immediately before daily dose) and peak ( } 2 \text { hours after daily dose) time intervals. In } \\
\text { univariate analysis, only the methadone dose was significantly associated with the magnitude of the QTc } \\
\text { increase from baseline to } 6 \text { months }(\mathrm{r}=0.18, \mathrm{p}=0.03) \text {. In multivariate analysis, controlling for all factors } \\
\text { associated with the baseline QTc interval and use of heroin, cocaine, and/or benzodiazepines, factors that were } \\
\text { associated with greater QTc prolongation from baseline to } 6 \text { months, included male gender, HIV infection, and } \\
\text { methadone dose. In multivariate analysis after } 12 \text { months, methadone dose remained marginally associated } \\
\text { with the magnitude of the QTc increase }(\mathrm{p}=0.08) \text {. The QTc interval change from baseline to } 12 \text { months was } \\
\text { significantly correlated with the methadone trough }(\mathrm{r}=0.37, \mathrm{p}=0.008) \text { and peak levels }(\mathrm{r}=0.32, \mathrm{p}=0.03) \text {. }\end{array}$ \\
\hline
\end{tabular}

yl-Daspartate (NMDA) receptor in rat forebrain and spinal cord. Neurosci. Lett. 223, 5-8 (1997).

6. Corkery JM, Schifano F, Ghodse AH, Oyefeso A. The effects of methadone and its role in fatalities. Hum Psychopharmacol. 2004;19:565-76.

7. Eap, C.B., Buclin, T. \& Baumann, P. Interindividual variability of the clinical pharmacokinetics of methadone: implications for the treatment of opioid dependence. Clin. Pharmacokinet.41, 1153-1193 (2002).

8. Gerber, J.G., Rhodes, R.J. \& Gal, J. Stereoselective metabolism of methadone N-demethylation by cytochrome P4502B6 and 2C19. Chirality 16, 36-44 (2004).

9. Crettol, S. et al. Methadone enantiomer plasma levels CYP2B6, CYP2C19 and CYP2C9 genotypes, and response to treatment. Clin. Pharmacol. Ther. 78, 593-604 (2005).

10. McCance-Katz EF, Sullivan LE, Nallani S. Drug interactions of clinical importance among the opioids, methadone and buprenorphine, and other frequently prescribed medications: a review. Am J Addict 2010; 19:4-16.

11. Faggiano F, Vigna-Taglianti F, Versino E, Lemma P. Methadone maintenance at different dosages for opioid dependence. Cochrane Database Syst Rev 2003; 3: CD002208

12. Lasser KE, Allen PD, Woolhandler SJ, Himmelstein DU, Wolfe SM, Bor DH. Timing of new black box warnings and withdrawals for prescription medications. JAMA 2002;287:2215-20.

13. Bazett HC. An analysis of the time-relations of electrocardiograms. Heart 1920; 7:353-70.

14. Committee for Proprietary Medicinal Products (CPMP). Points to consider: the assessment of the potential for QT interval prolongation by non-cardiovascular medicinal products. The European Agency for the Evaluation of Medicinal Products. December 1997 [CPMP/986/96].
15. Priori SG, Schwartz PJ, Napolitano C, et al. Risk stratification in the long-QT syndrome. N Engl J Med 2003;348:1866-74. 16. Sanguinetti, M.C, Jiang, C, Curran, M.E. \& Keating, M.T. A mechanistic link between an inherited and an acquired cardiac arrhythmia: HERG encodes the IKr potassium channel. Cell 81, 299-307 (1995).

17. Katchman, A.N. et al. Influence of opioid agonists on cardiac humanether-a-go-go-related gene $\mathrm{K}+$ currents. J. Pharmacol. Exp. Ther. 303,688-694 (2002). xxx. Kornick, C.A. et al. QTc interval prolongation associated with intravenous methadone. Pain 105, 499-506 (2003).

18. Kornick, C.A. et al. QTc interval prolongation associated with intravenous methadone. Pain 105, 499-506 (2003).

19. Wieneke H, Conrads H, Wolstein J, Breuckmann F, Gastpar M, Erbel R, Scherbaum N. Levo-alphaacetylmethadol (LAAM) induced QTc-prolongation - results from a controlled clinical trial. Eur J Med Res. 2009 Jan $28 ; 14(1): 7-12$.

20. Wedam EF, Bigelow GE, Johnson RE, Nuzzo PA, Haigney MC. QT-interval effects of methadone, levomethadyl, and buprenorphine in a randomized trial. Arch Intern Med. 2007 Dec 10;167(22):2469-75.

21. Krantz M. Heterogeneous Impact of Methadone on the QTc Interval: What Are the Practical Implications? J Addict Dis. 2008;27(4):5-9.

22. Krantz M, Lowery C, Martell B, Gourevitch M and Arnsten J. Effects of Methadone on QT-Interval Dispersion. Pharmacotherapy 2005;25(11):1523-1529.

23. Martell B, MD, Arnsten J, Krantz M, and Gourevitch M. Impact of Methadone Treatment on Cardiac Repolarization and Conduction in Opioid Users. Am J Cardiol 2005;95:915-918 
24. Maremmani I, Pacini M, Cesaroni C, Lovrecic M, Perugi $\mathrm{G}$, Tagliamonte $\mathrm{A}$. QTc interval prolongation in patients on long-term methadone maintenance therapy. Eur Addict Res. 2005;11(1):44-9.

25. Mayet S, Gossop M, Lintzeris N, Markides V, Strang J. Methadone maintenance, QTc and torsade de pointes: who needs an electrocardiogram and what is the prevalence of QTc prolongation? Drug Alcohol Rev. 2011 Jul;30(4):388-96.

26. MHRA and Commission on Human Medicines. Risk of QT interval prolongation with methadone. 2006 May. Report No.: 31.

27. Perrin-Terrin A, Pathak A, Lapeyre-Mestre M. QT interval prolongation: prevalence, risk factors and pharmacovigilance data among methadone-treated patients in France. Fundam Clin Pharmacol. 2011 Aug;25(4):503-10.

28. Anchersen K, Clausen T, Gossop M, Hansteen V, Waal H. Prevalence and clinical relevance of corrected QT interval prolongation during methadone and buprenorphine treatment: a mortality assessment study. Addiction. 2009 Jun;104(6):993-9.

29. Peles E, Bodner G, Kreek MJ, Rados V, Adelson M. Corrected-QT intervals as related to methadone dose and serum level in methadone maintenance treatment treatment (MMT) patients: a cross-sectional study. Addiction. 2007 Feb;102(2):289-300.

30. Eap CB, Crettol S, Rougier JS, Schlapfer J, Sintra Grilo L, Deglon JJ, Besson J, Croquette-Krokar M, Carrupt
PA, Abriel H. Stereoselective Block of hERG Channel by (S)-Methadone and QT Interval Prolongation in CYP2B6 Slow Metabolizers. Clin Pharmacol Ther. 2007 May; 81(5):719-28.

31. Routhier DD, Katz KD, Brooks DE. QTc prolongation and torsades de pointes associated with methadone therapy. J Emerg Med. 2007 Apr;32(3):275-8. Epub 2007 Feb 2.

32. Lamont P, Hunt SC. A twist on torsade: a prolonged QT interval on methadone. J Gen Intern Med. 2006 Nov;21(11):C9-C12.

33. Sanchez Hernandez AM, Atienza Fernandez F, Arenal Maiz A, Gonzalez Torrecilla E, Puchol Calderon A, Almendral Garrote J. Torsades de pointes during methadone treatment. Rev Esp Cardiol. 2005 Oct;58(10):1230-2.

34. U.S. Food and Drug Administration. Guidance for Industry: E14 Clinical Evaluation of QT/QTc Interval Prolongation and Proarrhythmic Potential for NonAntiarrhythmic Drugs. Center for Drug Evaluation and Research, Food and Drug Administration, Rockville, Maryland; 2005.

35. Roden DM. Drug-induced prolongation of the QT interval. N Engl J Med. 2004 Mar 4;350(10):1013-22.

36. Anchersen K, Hansteen V, Gossop M, Clausen T, Waal H. Opioid maintenance patients with QTc prolongation: congenital long QT syndrome mutation may be a contributing risk factor. Drug Alcohol Depend. 2010 Dec 1;112(3):216-9. doi: 10.1016/j.drugalcdep.2010.06.015. Epub 2010 Aug 10. 